Studia Judaica 24 (2021), nr 1 (47), s. 17-39

doi:10.4467/24500100STJ.21.002.14604

Szoszana Keller iD https://orcid.org/0000-0001-5388-459X

\title{
Kobiece micwot - rola i pozycja kobiety w świetle religijnego prawa żydowskiego
}

\author{
WOMEN'S MITZVOT: THE ROLE AND POSITION OF WOMEN \\ IN THE LIGHT OF THE JEWISH RELIGIOUS LAW
}

\begin{abstract}
It is not possible to understand the history and present day of Jewish women without placing them in the Jewish tradition, resulting mainly from religion which for centuries was the foundation of Jewish life, regulating its finest aspects. The article describes how the regulations of the religious Jewish law, halakha, determine the place of Jewish women in traditional society, and how the resulting adjustments relate to Jews according to gender. The analysis covers three so-called special women's mitzvot, i.e. the lighting of the Sabbath lights, the separation of the challah, and the observance of the laws related to the family purity, as well as the resulting positioning of women within a clear apportionment into female-male, public-domestic, or culture-nature.
\end{abstract}

Keywords: Jewish law, women, Jewish women, mitzvot, Judaism, orthodoxy.

Słowa kluczowe: prawo żydowskie, kobiety, Żydówki, micwot, judaizm, ortodoksja.

\section{Wstęp}

Życie każdego religijnego Żyda toczy się według ściśle określonych reguł wynikających z prawa religijnego zwanego halacha. Słowo halacha pochodzi od rdzenia oznaczającego 'iść', 'postępować' i odnosi się zarówno do prawa religijnego, jak i cywilnego. Rdzeniem całego systemu prawnego judaizmu jest Pięcioksiąg Mojżeszowy, jednakże rozwinięcie, uszczegółowienie i kierunek interpretacji wskazane zostały w Talmudzie. Pięć pierwszych ksiąg Biblii, zwanych Torą Pisaną (Tora Sze-bi-chtaw), oraz Talmud, określany 
mianem Tory Ustnej (Tora Sze-be-al-pe), razem tworzą Pełną Torę (Tora Szlema), która według wyznawców judaizmu została dana Mojżeszowi na górze Synaj ${ }^{1}$. To właśnie Tora Szlema stanowi podstawę późniejszych kodyfikacji, takich jak Miszne Tora ${ }^{2}$, Arbaa turim ${ }^{3}$ czy Szulchan aruch ${ }^{4}$, obowiązujących wyznawców judaizmu do dziś.

Istota judaizmu, zwanego religią prawa, jest przestrzeganie 613 przykazań objawiające się w czynach i działaniu, nie zaś w uczuciach czy emo$\operatorname{cjach}^{5}$. Stopień doskonałości religijnej mierzony jest więc gorliwością w przestrzeganiu i wypełnianiu przepisów halachy, zgodnie zaś z wierzeniami wyznawców judaizmu - wszystkie czyny dokonywane w świecie materialnym oddziałują bezpośrednio na wymiar duchowy. Upraszczając, można stwierdzić, że wszelkie podejmowane przez Żyda czynności mogą mieć charakter religijny. Prawo żydowskie określa więc nie tylko zasady dotyczące modlitwy i sprawowania nabożeństw, lecz również całokształt funkcjonowania zarówno poszczególnych jednostek, jak i społeczeństwa jako całości. Halacha reguluje każdy najdrobniejszy nawet aspekt życia, a także określa role i funkcje społeczne poszczególnych jego członków.

W niniejszym artykule postaram się pokazać, jak w świetle halachy kształtowała się rola i pozycja kobiety w tradycyjnym, ortodoksyjnym społeczeństwie żydowskim.

Tradycyjna społeczność żydowska funkcjonuje w sposób skategoryzowany i opiera się na opozycjach binarnych: Żydzi-inne narody (gojim), koszerne-niekoszerne, życie-śmierć, domowe-publiczne, natura-kultura i wreszcie kobiety-mężczyźni. Tak skonstruowany system wynika bezpośrednio z przekazu biblijnego, ma więc silną i nienaruszalną podstawę teonomiczną,

Od samego początku kultura żydowska opierała się na systemie patriarchalnym. Kategorię pierwszą stanowili mężczyźni - przywódcy, kapłani, uczeni, do drugiej natomiast należały kobiety - poddane, funkcjonujące poza sferą przestrzeni publicznej. Przy czym pojęcie płci, zarówno tej

${ }^{1}$ Sacha Pecaric, Wstęp, [w:] Zew Greenwald, Bramy halachy. Religijne prawo żydowskie, red. Sacha Pecaric, tłum. Joanna Białek, Kraków 2005, s. 22.

${ }^{2}$ Mosze ben Majmon zwany Rambam [dalej: Rambam], Miszne Tora - kodeks prawa religijnego powstały w latach $1170-1180$.

3 Jaakow ben Aszer, Arbaa turim - kodeks prawa religijnego powstały w latach 1300-1340, znany również pod tytułem Tur.

${ }^{4}$ Josef Karo, Szulchan aruch - czteroczęściowy kodeks prawa religijnego opublikowany po raz pierwszy w latach 1550-1559.

${ }_{5}$ Pecaric, Wstęp..., s. 27. 
w sensie biologicznym, jak i społeczno-kulturowym, postrzegane jest jako fakt przedspołeczny, uniwersalny, wywodzący się bezpośrednio z natury rzeczy.

Pojęcie kobiecości w prawie żydowskim zdeterminowane jest oddzielnym statusem prawnym, w różnym stopniu kształtującym każdy stosunek prawny ${ }^{6}$. Określenie praw i obowiązków jednostek przez nadanie im odmiennego statusu prawnego, zawsze intencjonalne, służy nie tylko ochronie poszczególnych członków społeczeństwa, ale także nadaniu temu społeczeństwu odpowiednich struktur oraz późniejszej kontroli tych struktur. Cele te niejednokrotnie są na tyle rozległe i niejasno określone, że nie ma możliwości, aby jednoznacznie sformułować zasadę, na podstawie której tworzony jest dany status prawny. Ponadto niemożliwe jest później sprecyzowanie konkretnych rozróżnień w przepisach prawa, dzięki którym zakładany cel miałby być osiągnięty. Przykładem takiej właśnie sytuacji jest prawo żydowskie, gdzie w Talmudzie brakuje generalnej reguły definiującej status kobiety jako podmiotu praw i obowiązków ${ }^{7}$. Jest on zazwyczaj określany na podstawie pojedynczego przepisu.

\section{Kobieta i micwot}

W jaki więc sposób przepisy prawa kształtowały status kobiety? Jak wspomniano wyżej, dla ortodoksyjnych wyznawców judaizmu halacha stanowi podstawę wszelkich stosunków społecznych i reguluje je niemalże całkowicie. Podstawą jest 613 przykazań wynikających bezpośrednio z Tory, w tym 365 negatywnych (micwot lo taase) oraz 248 pozytywnych (micwot ase) - większość z nich odnosi się zarówno do kobiet, jak i mężczyzn, np. nakaz przestrzegania szabatu, prawa dotyczące koszerności czy zakaz bałwochwalstwa. Istnieją jednak takie micwot, które dotyczą wyłącznie określonej płci, jak obrzezanie w przypadku mężczyzn i prawa związane z nida odnoszące się do kobiet. Pojawiają się również micwot, które nie są związane z płcią biologiczną, a jednak dotyczą konkretnej płci, np. obowiązek wykupu pierworodnego syna, obowiązek rozmnażania się czy studiowania Tory ${ }^{8}$. Przykazania te, chociaż niezwiązane z płcią biologiczną,

${ }^{6}$ Saul J. Berman, The Status of Women in Halakhic Judaism, „Tradition” 14 (1973), nr 2, s. 11.

7 Tamże.

${ }^{8}$ Rachel Biale, Women and Jewish Law: An Exploration of Women's Issue in Halakhic Sources, New York 1984, s. 10. 
opierają się na różnicach w pojmowaniu ról płciowych w tradycyjnej społeczności żydowskiej.

Wykluczenie kobiet z niektórych przykazań nie zostało bezpośrednio sformułowane w Pięcioksięgu. Jednak już w Misznie można znaleźć następujący zapis: „Wszystkie pozytywne przykazania, które są określone w czasie, mężczyźni są zobowiązani wypełniać, a kobiety nie" (Miszna, Kiduszin $1: 7)^{9}$. Z cytowanego tu fragmentu wynika, że kobiety zobowiązane są do przestrzegania trzech rodzajów przykazań: wszystkich przykazań negatywnych, zarówno tych określonych, jak i nieokreślonych w czasie, oraz przykazań pozytywnych nieokreślonych w czasie. Halacha zwalnia je natomiast z wypełniania przykazań pozytywnych związanych z czasem. Od tak sformułowanej zasady istnieją wyjątki. Mosze ben Majmon zwany Rambam (1136-1204) w Sefer ha-micwot sformułował sześćdziesiąt pozytywnych przykazań, które zwykły człowiek jest zobowiązany wypełniać w życiu codziennym. Kobiety są zwolnione z czternastu z nich, przy czym osiem jest określonych w czasie. Z drugiej jednak strony Rambam wymienia sześć pozytywnych przykazań określonych w czasie, które obowiązują kobiety. Dodatkowo wylicza pozytywne przykazania rabiniczne związane z czasem, które jego zdaniem również są dla kobiet obowiązujące ${ }^{10}$. Wynika z tego, że liczba pozytywnych micwot związanych z czasem, z której kobiety są zwolnione, jest niemalże taka sama jak ta, która je obowiązuje. Nie można więc mówić w tym przypadku o istnieniu zasady generalnej. Wydaje się zatem, że stanowisko zawarte w Misznie wyewoluowało z codziennych praktyk lub powstało w wyniku orzeczeń w poszczególnych, konkretnych przypadkach, które nabrały charakteru precedensu. W każdym z tych przypadków można stwierdzić, że wyłączenie kobiet $\mathrm{z}$ wykonywania pozytywnych micwot określonych w czasie nie ma charakteru logiczno-prawnego, lecz raczej społeczno-kulturowy ${ }^{11}$. Kobiety zobowiązane są zatem do przestrzegania tych praw, które zgodne są ze statusem kobiety w tradycji żydowskiej, oraz nieprzestrzegania tych, które z tym statusem kolidują.

Miszna nie określa przyczyn wyłączenia kobiet z przestrzegania pewnej części przykazań. Według większości komentatorów takie rozwiązanie

${ }^{9}$ Podstawą źródłową tekstów biblijnych i pobiblijnych nieopatrzonych osobnymi przypisami jest elektroniczna edycja Sefaria: A Living Library of Jewish Texts, https://www. sefaria.org/texts. Tłumaczeń tekstów źródłowych nieopatrzonych osobnym przypisem dokonała autorka artykułu. Wszystkie cytaty z Talmudu pochodzą z Talmudu babilońskiego [dalej: TB].

${ }^{10}$ Podaję za: Berman, The Status of Women..., s. 12.

${ }^{11}$ Biale, Women and Jewish Law..., s. 17. 
wynika przede wszystkim ze społecznej roli kobiety jako żony i matki. I to właśnie ta rola określa pozycję kobiety w społeczeństwie. Podstawą żydowskiego życia społecznego jest rodzina. Kobieta - żona i matka - nazywana jest po hebrajsku akeret ha-bajt - pani domu (od słowa ikar), ponieważ jest podstawą, zasadą domu. Talmud w sposób zdecydowany podkreśla rolę kobiety w kształtowaniu życia rodzinnego i jej wpływ na życie męża. Tradycja żydowska stworzyła więc dla kobiety rolę, według której jedyną sferą umożliwiającą jej spełnienie jest dom i rodzina.

Z koncepcją tą koresponduje wyjaśnienie Dawida ben Josefa Abudarhama (połowa XIV w.), który twierdził, że powodem zwolnienia kobiety z wykonywania pozytywnych przykazań określonych w czasie jest fakt, że jest ona zobowiązana do spełniania potrzeb męża:

Gdyby była zobowiązana do przestrzegania określonych w czasie przykazań pozytywnych, byłoby możliwe, że podczas wykonywania micwy mąż kazałby jej wykonać micwę na jego rzecz. Gdyby wykonała nakaz Stwórcy i odłożyła na bok nakaz swojego męża, biada jej mężowi! Jeśli wykona nakaz męża i odłoży na bok nakaz Stwórcy, biada jej Stwórcy! Dlatego Stwórca dla zachowania pokoju pomiędzy nią a jej mężem zwolnił ją od swoich micwot ${ }^{12}$.

Kobieta jest więc sprowadzona do roli służebnej wobec mężczyzny. W przedstawionej powyżej myśli zawiera się jeszcze jedna koncepcja statusu kobiety w tradycyjnym judaizmie: kobieta jest przedmiotem rywalizacji między Bogiem a mężem, którzy posiadają nadrzędną pozycję w stosunku do niej.

W dalszej części artykułu postaram się przyjrzeć temu, w jaki sposób religijne prawo żydowskie określało zakres religijnych kompetencji kobiet odnoszący się do najważniejszych zagadnień, takich jak modlitwa czy studia religijne.

\section{Modlitwa}

Modlitwa jest podstawową aktywnością każdego religijnego Żyda. Miszna stwierdza: „Kobiety, niewolnicy i nieletni są zwolni z recytowania Szema, nakładania filakterii, ale ich obowiązkiem jest modlitwa, mezuza i błogosławieństwo po posiłku" (Miszna, Berachot 3:3). Mimo że kobiety nie mają takiego samego statusu prawnego jak niewolnicy czy nieletni, ujęcie ich w tej samej grupie już na wstępie może wskazywać, iż ich udział w życiu

12 Dawid ben Josef Abudarham, Sefer Abudarham, Szaar 3, Birkat ha-micwot. 
religijnym ma drugorzędną rolę ${ }^{13}$. W traktacie Berachot 20b wyróżnia się trzy typy modlitwy: recytowanie Szema, modlitwa o Boże miłosierdzie oraz błogosławieństwo po posiłku. Jakkolwiek pierwszy i trzeci typ to modlitwy określone, drugi zdaje się odnosić do modlitwy generalnie. Szlomo ben Jicchak zwany Raszi (1040-1105) uważa, że kobiety są zobowiązane do modlitwy, gdyż tak jak mężczyźni potrzebują Boskiego miłosierdzia ${ }^{14}$. W tradycji religijnej to właśnie kobieta - biblijna Chana - jest wzorem modlitwy błagalnej (TB, Berachot 31a). Według kodeksu prawa żydowskiego Szulchan aruch kobieta, mimo że zwolniona z recytowania Szema, jest zobowiązana do modlitwy, gdyż ta w swej istocie nie jest związana z czasem ${ }^{15}$. Na tej podstawie widać, że kobiety mają wyraźny obowiązek modlitwy, nie jest on jednak identyczny z tym, który został nałożony na mężczyzn. Awraham Abele Gombiner (ok. 1635-1682) w rozprawie Magen Awraham, będącej komentarzem do Szulchan aruch, rozróżnił modlitwę męską i kobiecą, stwierdzając, że modlitwa kobieca jest prywatna i indywidualna - w przeciwieństwie do skodyfikowanej modlitwy męskiej ${ }^{16}$. Uczestnictwo w modlitwie wraz ze społecznością pozostawało dla kobiety kwestią wyboru.

Kolejnym aspektem różniącym modlitwę męską od kobiecej jest forum, na którym ta modlitwa się odbywa, wiążące się bezpośrednio z pojęciem minjanu. Jak wspomniano wyżej, modlitwa kobieca jest indywidualna i prywatna. Modlitwa mężczyzn jest najczęściej publiczna i niezbędne jest dla niej zebranie kworum dziesięciu dorosłych mężczyzn - minjan. Obecność minjanu niezbędna jest m.in. do czytania Tory, haftary czy recytacji kadiszu, mimo że rabini nie są zgodni w tym, czy modlitwa w minjanie jest micwą, czy też nie ${ }^{17}$; większość autorytetów religijnych podkreśla, że ma ona większą wartość niż modlitwa prywatna ${ }^{18}$. W literaturze rabinicznej panuje dość jednoznaczne stanowisko co do tego, że kobiety nie są do minjanu liczone. Uzasadniano to faktem, że są one zwolnione z modlitw w zgromadzeniu jako oznaczonych w czasie. Pojawiło się jednak pytanie dotyczące liczenia kobiet do modlitewnego kworum wtedy, gdy były one

13 Biale, Women and Jewish Law..., s. 18.

14 Szlomo ben Jicchak zwany Raszi [dalej: Raszi], Komentarz do Berachot 20b.

15 Karo, Szulchan aruch, Orach chajim 106:2.

16 Awraham Abele Gombiner, Magen Awraham 106:2.

17 Raszi uważał, że modlitwa w minjanie jest micwą (komentarz do Pesachim 46a), natomiast w ocenie Moszego ben Nachmana zwanego Ramban [dalej: Ramban] modlitwa z minjanem nie stanowi indywidualnej micwy, w związku z czym nie ma obowiązku aktywnego szukania minjanu - Ramban, Milchamot ha-Szem, Megila 5a.

18 Raszi, Komentarz do Pesachim 46a. 
zobowiązane do uczestniczenia na równi z mężczyznami. Przykładem takiej sytuacji jest odczytywanie Księgi Estery w coroczne święto Purim. W Talmudzie rabbi Joszua ben Lewi stwierdził, że ponieważ cud purimowy obejmował w równym stopniu mężczyzn i kobiety, w takim samym więc stopniu są oni zobligowani do czytania Megilat Ester (TB, Megila 44a). $\mathrm{Z}$ obowiązku tego można być zwolnionym poprzez wysłuchanie czytania, jeśli zarówno słuchający, jak i czytający mają taką intencję. W praktyce więc Megilat Ester odczytywana jest publicznie w synagodze i powinno się to odbywać w obecności minjanu. Czy zatem w takim przypadku należy kobiety do niego wliczać? Nissim ben Reuwen z Gerony (1320-1376) odpowiedział na to pytanie twierdząco, zakładając, że niesprawiedliwe jest, gdy kobiety pomagają wypełniać mężczyznom przykazanie i nie są liczone do kworum. Powinny być więc liczone, zwłaszcza że spoczywający na nich obowiązek jest taki sam jak obowiązek mężczyzn ${ }^{19}$. Opinia ta nigdy nie zyskała szerszego uznania, a zatem nawet wtedy, gdy obecność kobiety podczas modlitw publicznych związana jest z nałożonym na nią obowiązkiem religijnym, nie jest ona liczona do minjanu. Wydaje się, że stanowisko rabinów w tej kwestii wynika przede wszystkim z jednoznacznego umiejscowienia kobiet poza sferą publiczną.

\section{Kobieta i Naród Księgi}

Jednym z najważniejszych momentów szabatowego nabożeństwa jest publiczne odczytanie cotygodniowego fragmentu Tory. Obowiązek czytania Tory wywodzi się bezpośrednio z Biblii:

I rozkazał im Mojżesz: „Po upływie siedmiu lat, w roku darowania długów, w czasie Święta Namiotów, gdy cały Izrael się zgromadzi, by oglądać oblicze Pana, Boga twego, na miejscu, które On sobie obierze, będziesz czytał to Prawo do uszu całego Izraela. Zbierz cały naród: mężczyzn, kobiety i dzieci, i cudzoziemców, którzy są w twoich murach, aby słuchając uczyli się bać Pana, Boga waszego, i przestrzegać pilnie wszystkich słów tego Prawa" (Pwt 31:10-12) ${ }^{20}$.

Jak wynika z powyższego fragmentu, Tora była odczytywana w całości jedynie raz na siedem lat, a kobiety na równi z mężczyznami zobowiązane były do jej wysłuchania. Jeśli więc obowiązek cotygodniowego czytania Tory

${ }^{19}$ Podaje za: Aryeh Frimer, Women and Minyan, „Tradition” 23 (1988), nr 4, s. 58.

${ }^{20}$ Wszystkie cytaty biblijne w thumaczeniu na język polski podano na podstawie edycji Biblia Tysiaclecia. Pismo Święte Starego i Nowego Testamentu, Poznań 2019. 
wywodzi się bezpośrednio z prawa biblijnego, powinien on dotyczyć na równi mężczyzn i kobiet. Żyjący w V w. p.n.e. Ezra zainicjował obowiązujący współcześnie rytuał czytania Tory w poniedziałki, czwartki i w szabat, jednak jego kodyfikacja nie wskazywała już kobiet jako zobowiązanych do brania w nim udziału, jak to czynił tekst Biblii. Zdaniem wielu autorytetów rabinicznych czytanie Tory jest tożsame z jej studiowaniem i wypełnia nakaz zawarty w Księdze Powtórzonego Prawa 6:7. Ponieważ kobiety wyłączone są z obowiązku studiowania Tory, o czym szerzej później, na tej samej zasadzie są więc zwolnione z obowiązku jej czytania. Aby uniknąć sprzeczności z tekstem Pięcioksięgu, większość autorytetów religijnych uznała, że istniejący obecnie obowiązek czytania Tory wyprowadzić należy nie bezpośrednio z samej Tory, lecz z późniejszych reform Ezry. W konsekwencji tej decyzji micwa ta stała się określoną w czasie, czego efektem jest wyłączenie kobiet z tego obowiązku.

Brak obowiązku nie jest jednak tożsamy z zakazem. Talmud stoi na stanowisku, że status kobiety nie czyni jej niezdolną prawnie do czytania Tory, stwierdzając, że wszyscy mogą być do tego powołani, również kobiety i małoletni, jednak kobiety nie powinny czytać Tory ze względu na kewod ha-cibur - szacunek zgromadzenia (TB, Megila 23a). Jeżeli kobiety są zdolne do publicznego czytania Pięcioksięgu, a jedyną przeszkodą jest „szacunek zgromadzenia”, w jaki więc sposób ów szacunek należy rozumieć? Talmud nie precyzuje tego pojęcia. Zwyczajowo w odniesieniu do kobiet jest ono rozumiane na dwa sposoby. Część rabinów uważa, że „szacunek zgromadzenia" związany jest z pojęciem cnijut (skromności). Zgodnie z tym poglądem widok, a zwłaszcza głos kobiet - jako mocno nacechowane seksualnie - mogłyby działać na mężczyzn rozpraszająco, prowadząc do frywolności, a w konsekwencji do rozwiązłości. Czytanie przed mężczyznami byłoby więc niezgodne z zasadami skromności. Istnieje jednak wątpliwość, czy pojęcie ,szacunek zgromadzenia” związane jest z zagadnieniem cnijut. W literaturze rabinicznej istnieją utarte pojęcia odnoszące się do cnijut, takie jak mahszawot zarot (obce myśli), jecer ha-ra (zła siła), pricut (wyuzdanie) czy erwa (przestępstwa seksualne), wydaje się więc, że gdyby „szacunek zgromadzenia” miał związek z domniemanym wpływem kobiet na rozwiązłość mężczyzn, użyto by któregoś z wymienionych wyżej sformułowańn ${ }^{21}$. 
Według jednej z opinii zawartej w Talmudzie - jeżeli mąż nie jest wystarczająco uważny lub wystarczająco wykształcony, kobieta może powiedzieć błogosławieństwo po posiłku w jego zastępstwie, jednak zdaniem rabinów: „Niech przekleństwo [meira] spadnie na mężczyznę, którego żona i synowie mówią błogosławieństwo za niego" (TB, Berachot 20b). Kobieta jest więc z punktu widzenia prawa zdolna do odmawiania błogosławieństwa w zastępstwie męża, lecz pociąga to za sobą domniemanie, że nie posiada on wystarczających umiejętności, aby uczynić to samemu. W związku z tym, że to od mężczyzn wymaga się religijnych kompetencji, odgrywanie przez kobietę w ich obecności wiodącej roli w rytuale jest dla nich niehonorowe. Chociaż opisana sytuacja dotyczy honoru jednostki, a nie zgromadzenia, uznać można, że zasada jest taka sama. W przypadku zgromadzenia znaczenie może mieć również fakt, że kobiety nie są zobowiązane do publicznej modlitwy, nie są również liczone do minjanu, a zatem - jak zauważa współczesny rabin Gidon Rothstein: „Kiedy mężczyzna ma obowiązek i pozwala komuś, kto nie jest do tego zobligowany, przejąć inicjatywę, może to oznaczać, że nie dba o swoje rytualne obowiązki" ${ }^{22}$. Z tego wynika, że Torę powinni czytać mężczyźni, ilekroć jest to tylko możliwe, a powierzenie tej funkcji kobiecie oznacza pewne problemy z męską częścią społeczności, sprowadzając przy tym hańbę na tę społeczność. Widać zatem, że przepis ten jest związany ze statusem społecznym kobiet, określając je, jak w przypadku modlitw, jako członków społeczności drugiej kategorii, co szczególnie uwidacznia się w sferze publicznej.

$\mathrm{W}$ traktacie talmudycznym napisano:

W odniesieniu do wszystkich micwot syna w stosunku do ojca, mężczyźni są zobowiązani do ich wykonywania, a kobiety są z tego zwolnione. A w odniesieniu do wszystkich micwot ojca w stosunku do syna, obowiązani są je wykonywać zarówno mężczyźni, jak i kobiety (TB, Kiduszin 29a:6).

Fragment ten zawiera kolejną zasadę ograniczającą obowiązki religijne kobiet. Odnosi się on do takich micwot, jak: obrzezanie, wykupienie syna pierworodnego, nauka Tory, znalezienie żony oraz nauka zawodu (TB, Kiduszin 29b:10). Są to więc czynności mające na celu ukształtowanie następnego pokolenia wartościowych, religijnych Żydów. Powyższa micwa nie tylko zdejmuje z kobiet pewien religijny obowiązek, lecz de facto je

${ }^{22}$ Gidon Rothstein, Women's Aliyyot in Contemporary Synagogues, „Tradition” 39 (2005), nr 2, s. 49. 
z wykonywania tego obowiązku wyklucza ${ }^{23}$. Określa więc ona odrębne funkcje kobiety i mężczyzny jako matki i ojca. Halacha ta jest ciekawa, gdyż kontrastuje z powszechnie panującą wizją żydowskiej matki, która stanowi centralną część żydowskiego domu i na której spoczywa niemalże całkowita odpowiedzialność za wychowanie dzieci. Tymczasem Tora Ustna nakłada ten obowiązek na ojca.

Studiowanie Tory jest najważniejszym obowiązkiem w życiu każdego religijnego Żyda, traktowanym jako najwyższa forma pracy ${ }^{24}$. Mimo że ta pozytywna micwa wydaje się niezwiązana z czasem, co do możliwości podejmowania takich studiów przez kobiety autorytety religijne zmieniały swoje poglądy na przestrzeni kształtowania się prawa i tradycji żydowskiej, przyjmując niejednokrotnie skrajne stanowiska.

W okresie tanaitów (I-II w. n.e.) obowiązywały trzy stanowiska odnoszące się do studiowania Tory przez kobiety. Pierwsze reprezentował Ben Azzai zalecający nauczanie kobiet Tory na równi z mężczyznami (TB, Sota 20a). Wydaje się, że jego poglądy znalazły odzwierciedlenie w przyjętym w tamtym okresie zwyczaju, potwierdzonym przez licznie ukazane na kartach Talmudu historie uczonych kobiet, których najbardziej znanym przykładem jest Bruria - żona rabbiego Meira (TB, Eruwin 53b, Nedarim 50b). Żyjący w tym samym okresie rabbi Eliezer był natomiast stanowczym przeciwnikiem nauczania kobiet Tory (TB, Sota 20a). Podobny pogląd wyrażał Eleazar ben Azaria. Interpretując wers: „Zbierz cały naród: mężczyzn, kobiety i dzieci, i cudzoziemców, którzy są w twoich murach, aby słuchając uczyli się bać Pana, Boga waszego" (Pwt 31:12), twierdził on, że ,jeśli mężczyźni przyjdą się uczyć, kobiety, które mogą nie rozumieć, przyjdą przynajmniej posłuchać" (TB, Chagiga 3a). Tosefta (Berachot 12,2) przyjmuje pozycję pośrednią, reprezentując pogląd, że chociaż kobiety nie mają obowiązku studiowania Tory, nie jest to zabronione.

Amoraici (III-V w. n.e.) przyjęli stanowisko prezentowane w Tosefcie, podkreślając jednocześnie brak obowiązku (TB, Kiduszin 29a), a tym samym wskazując na mniejszą wagę kobiecych studiów.

W okresie riszonim (XI-XV w. n.e.) jako obowiązujący przyjęto pogląd rabbiego Eliezera, tym samym zakazując kobietom studiów religijnych. Rabbi Eliezer sformułował swoje stanowisko w następujący sposób: „Każdy, kto uczy swoją córkę Tory to tak, jakby nauczał ją tiflut" (TB, Sota 20a). Rabini nie wypracowali jednolitego stanowiska co do znaczenia słowa

23 Biale, Women and Jewish Law..., s. 30.

24 Tamże, s. 28. 
tiflut. Raszi uważał, że oznacza ono 'niemoralność'25, według Rambama należało je tłumaczyć jako 'trywialność', 'bzdurnośćp'. Rambam, cytując opinię rabbiego Eliezera, wyjaśnia, że intencją kobiet, nawet jeśli podejmują studia, tak naprawdę nie jest zdobycie wiedzy i wykształcenia religijnego. Dodaje także, że kobiety mają ograniczone możliwości poznawcze i jeśli będą studiowały Torę, sprowadzą jej treść do nonsensu. W związku z tym uczenie kobiet to nie tylko bezsensowne przedsięwzięcie, ale również niebezpieczeństwo, że wypaczą znaczenie świętego tekstu. Słowa rabbiego Eliezera rabini ograniczyli jednak wyłącznie do Tory Ustnej. W odniesieniu do Tory Pisanej nie byli już tak restrykcyjni, uznając, że wprawdzie ojcowie nie powinni uczyć córek, jednak jeżeli już ktoś to zrobił, to nie jest to tiflut. Mimo przyjęcia stanowiska prezentowanego przez rabbiego Eliezera Rambam uważał, że kobieta studiująca Torę zasługuje na nagrodę, ale mniejszą niż mężczyzna, ponieważ nie jest do tego zobowiązana, lecz czyni to jedynie $\mathrm{z}$ własnej woli. Zgodnie $\mathrm{z}$ halachą wypełnianie micwot $\mathrm{z}$ obowiązku ma dużo większą wartość niż wypełnianie tych samych micwot z własnej woli - jest to powszechnie przyjęty pogląd odnoszący się nie tylko do kobiet.

Jednak w prezentowanych wyżej poglądach Rambama widać sprzeczność, z jednej bowiem strony studiowanie Tory przez kobiety postrzega on jako czynność zasługującą na nagrodę, z drugiej zaś uważa, że kobiety nie powinny studiować, gdyż są do tego niezdolne intelektualnie i w najlepszym wypadku strywializują treść Prawa. Joszua ben Aleksander ha-kohen Falk (1555-1614) w swych komentarzach pt. Perisza rozwiązuje tę niespójność, zauważając, że gdyby kobieta z powodzeniem samodzielnie studiowała Torę, nie byłaby klasyfikowana wraz z resztą kobiet, a w konsekwencji zakaz nie miałby do niej zastosowania, więc ojciec mógłby ją uczyć. Jednak dopóki jej umiejętności pozostają nieznane, dopóty jej ojciec ma zakaz nauczania ${ }^{27}$. Jak wspomniano wyżej, dychotomiczny podział na „kobiece” $\mathrm{i}$ „męskie” w tradycyjnym judaizmie jest jednoznaczny, a jego granice są nieprzekraczalne. Jako że cechą kobiet, jak twierdzili rabini, był brak zdolności intelektualnych, posiadanie takich zdolności, jednoznacznie kojarzonych $\mathrm{z}$ domeną męską, było tożsame $\mathrm{z}$ utratą statusu kobiety $\mathrm{w}$ tym zakresie - taka kobieta nie była klasyfikowana z resztą kobiet. Stanowisko zawarte w Perisza, mimo pozornego otwarcia drogi dla kobiecej edukacji,

\footnotetext{
25 Raszi, Komentarz do Sota 21b.

26 Rambam, Miszne Tora, Hilchot Talmud Tora 1:13.

27 Joszua ben Aleksander ha-kohen Falk, Perisza, Tur Jore dea 246:6.
} 
jest potwierdzeniem poglądu, że studia religijne nierozerwalnie łączono z mężczyznami. Nawet jeżeli teoretycznie nie były one całkowicie kobietom zakazane, w praktyce na ich podjęcie miały szansę jedynie nieliczne wyjątki, a ocena, czy kobieta stanowi dany wyjątek, czy nie, należała znów wyłącznie do mężczyzn.

Podobne zasady funkcjonowały także w okresie acharonim (od XVI w. n.e.), w którym kobiety mogły się uczyć jedynie tych fragmentów Tory Pisanej lub Tory Ustnej, które niezbędne były do prawidłowego wykonywania obowiązków domowych. Przy czym zakaz ten obejmował zarówno samodzielne uczenie się, jak i nauczanie przez mężczyzn (Tosefta, Sota 21b). Rabin Josef Karo w Szulchan aruch przyjął dosłownie opinię Rambama $^{28}$. Mosze ben Jisrael Iserl (1530-1572) w swoich komentarzach pojmował słowo tiflut jako 'niemoralność', akceptując w tej sprawie także poglądy Rasziego ${ }^{29}$. Odmienne natomiast zdanie wypowiedział Szneur Zalman z Ladów (1745-1813), założyciel dynastii chasydzkiej Chabad Lubawicz, określając micwę studiowania Tory (Ustnej i Pisanej) jako obligującą kobiety na równi z mężczyznami, z wyjątkiem przepisów dotyczących micwot nieobowiązujących kobiet ${ }^{30}$. Było to jednak stanowisko odosobnione.

Wyłączenie kobiet z micwy studiowania Tory wyprowadzono także z fragmentu traktatu Kiduszin 29a:6 poruszającego kwestię obowiązku rodziców wobec dzieci, o którym wspomniano wcześniej. W tekście tym stwierdzono, że to ojciec zobowiązany jest do przekazania synowi wiedzy wynikającej z Tory. Z tego też fragmentu rabini wywnioskowali, że tylko ten jest zobowiązany do uczenia się, kto jest również zobowiązany do nauczania, a ponieważ wynikający z Tory obowiązek nauczania odnosi się wyłącznie do mężczyzn - „I będziesz nauczał ich swoich synów” (Pwt 11:19) - kobiety są z niego wyłączone ${ }^{31}$.

W opinii wielu autorytetów studiowanie Tory przez kobiety jest sprzeczne z tradycyjnym podziałem ról i wartościami, do których kobiety powinny dążyć, a dążenie w tej kwestii do równouprawnienia to zagrożenie dla panującego porządku. Czy w Narodzie Księgi halacha przewiduje jakąś rolę dla kobiety związaną z edukacją religijną? Odpowiedź pojawia się w Talmudzie:

\footnotetext{
${ }^{28}$ Karo, Szulchan aruch, Jore dea 246:6.

${ }^{29}$ Mosze ben Jisrael Iserl, Mapa, Komentarz do Szulchan aruch, Jore dea 246:6.

${ }^{30}$ Podaję za: Berman, The Status of Women..., s. 15.

${ }^{31}$ Zob. też TB, Kiduszin 29b.
} 
Większa jest obietnica złożona przez Świętego, niech będzie błogosławiony, kobietom niż mężczyznom, jak jest powiedziane: „Wstańcie, niewiasty spokojne; usłyszcie mój głos, pewne siebie córki, posłuchajcie, co mówię” (Izajasz 32:9). Raw powiedział do rabina Chiji: Jaką cnotą zasługują kobiety na otrzymanie tej nagrody? Rabin Chija odpowiedział: Zasługują na tę nagrodę za przyprowadzenie swoich dzieci na naukę w synagodze i za wysłanie mężów do studiowania Miszny w bejt midraszu oraz za czekanie na mężów, aż wrócą z bejt midraszu (TB, Berachot 17a:13-14).

W powyższym fragmencie Talmud jednoznacznie określa preferowaną rolę kobiety w tradycyjnym społeczeństwie. Dla potwierdzenia tych słów istnieje wiele historii opiewających pobożność i zasługi kobiet, które poświęciły swoje własne potrzeby i szczęście małżeńskie dla umożliwienia swoim mężom studiowania Tory. Najbardziej znana opowieść dotyczy Racheli, żony rabbiego Akiwy, która poślubiła go - mimo że był biednym i niewykształconym pasterzem - ponieważ obiecał studiować Torę. Przez dwadzieścia cztery lata żyła samotnie, odrzucona przez ojca, w biedzie, podupadając na zdrowiu. W tym czasie rabbi Akiwa studiował, zyskując miano rosz la-chachamim - przywódcy mędrców. Dopiero w ostatnich latach życia powróciła do męża, otrzymując należny jej status (TB, Ketuwot 62b). Historie te mają być źródłem inspiracji, a opisane w nich kobiety - wzorem do naśladowania.

\section{Micwot kobiece}

Wśród 613 przykazań można znaleźć trzy odnoszące się wyłącznie do kobiet, tzw. specjalne kobiece micwot, które w sposób niebudzący wątpliwości określają pozycję kobiety w społeczności, ograniczając ją przede wszystkim do sfery domowej. Są to:

1. zapalanie świateł szabatowych - hadlakat nerot,

2. oddzielanie chala - hafraszat chala,

3. prawa związane z czystością życia rodzinnego - taharat ha-miszpacha.

Dla wyznawców judaizmu szabat jest najcenniejszym darem danym Izraelowi przez Stwórcę (TB, Szabat 10b). Dla uhonorowania tego wyjątkowego dnia w piątkowy wieczór w każdym żydowskim domu powinny zapłonąć szabatowe światła ${ }^{32}$. Chociaż przykazanie to nie wyklucza mężczyzn, zwyczajowo jest ono związane z kobietami. Zapalenie świec następuje na 18 do 40 minut przed zachodem słońca. W zależności od przyjętego w danej

${ }^{32}$ Raszi, Komentarz do Szabat 25b. 
społeczności zwyczaju zapala się co najmniej dwie świece. Niekiedy liczba świec jest równa liczbie domowników. Od momentu zapalenia świateł kobietę zaczynają obowiązywać zakazy szabatowe (w przeciwieństwie do mężczyzny, dla którego początek szabatu następuje wraz z wypowiedzeniem słów psalmu Mizmor szir le-jom ha-szabat) ${ }^{33}$. Zapalenie świec przez panią domu zwalnia z tego obowiązku pozostałych domowników. W związku z tym w tradycji żydowskiej kobieta jest uważana za tę, która sprowadza na swój dom światło będące metaforą Tory, ludzkiej duszy oraz świętości ${ }^{34}$. Jak już wspomniano, rolą kobiety jest wspieranie męża i synów w studiach religijnych, czego wyrazem jest obowiązek modlitwy podczas zapalania świateł szabatowych, aby Bóg pomógł dzieciom kobiety zostać uczonymi w Torze. Rambam przypisanie tej micwy kobietom tłumaczył kwestiami praktycznymi związanymi z podziałem obowiązków: micwa ta należała do kobiet, ponieważ to one przebywały w domu i prowadziły gospodarstwo domowe ${ }^{35}$. Po raz kolejny to, co domowe, powiązane zostało $\mathrm{z}$ kobiecością.

Chala to kawałek (wielkości oliwki) oddzielany podczas zagniatania ciasta sporządzanego z mąki z jednego z pięciu gatunków zbóż: pszenicy, jęczmienia, owsa, orkiszu, żyta. Obowiązek oddzielenia chala wynika $\mathrm{z}$ wersetu:

Tak do Mojżesza znów mówił dalej Pan: „Powiedz Izraelitom: Gdy przyjdziecie do kraju, do którego was prowadzę, zanim zaczniecie jeść chleb kraju, przyniesiecie wpierw dar szczególny dla Pana. Przyniesiecie w darze pierwociny ciasta, okrągły placek przyniesiecie jako szczególny dar klepiska. Będziecie składać pierwociny ciasta jako szczególny dar dla Pana przez [wszystkie] wasze pokolenia” (Lb 15:17-21).

Pierwotnie chala łączyła się ze służbą w Świątyni Jerozolimskiej i była jednym $z$ darów przynoszonych kohenom. W sensie biblijnym przykazanie to odnosi się wyłącznie do Ziemi Izraela. Po zburzeniu Świątyni micwa ta, jako rabiniczna ${ }^{36}$, ewoluowała, przechodząc ze sfery publicznej do domowej, i stała się jedną z trzech, które tradycja wiąże bezpośrednio z kobietami, na co wskazują słowa: „Ponieważ chala jest bezpośrednio związana z potrzebami domu, zaś kobieta znajduje się w domu, dlatego

33 Greenwald, Bramy halachy..., s. 189.

34 Josef Chajim z Bagdadu, Ben Jehojada, Komentarz do Szabat 32a.

35 Rambam, Miszne Tora, Szabat 3:3.

36 Karo, Szulchan aruch, Jore dea 322:2. 
jest związana z tym przykazaniem" ${ }^{37}$. Wydaje się więc, że takie rozwiązanie ma uzasadnienie praktyczne, ponieważ przygotowywanie posiłków, jako część prowadzenia domu, jest obowiązkiem kobiety, ale również wiąże się z łączeniem kobiecej duchowości ze sferą domową - prywatną. Część rabinów przypisanie tego obowiązku kobietom uzasadnia potrzebą odkupienia winy za sprowadzenie na ludzkość upadku - zgodnie z opinią: „Adam był chala świata, jak mówi werset: »Bóg stworzył Adama z prochu ziemi«. Kiedy kobieta miesza mąkę z wodą, musi oddzielić chala, aby zadośćuczynić za przestępstwo Chawy, która spowodowała upadek Adama" (TB, Szabat 20a:1).

Trzecią z kobiecych micwot jest taharat ha-miszpacha, która stanowi ogół praw związanych z tzw. czystością rodziny, czyli relacjami seksualnymi między małżonkami. Podobnie jak wszystkie czynności i zachowania - stosownie do wierzeń wyznawców judaizmu - życie seksualne można przeżywać w sposób święty, a żydowskie prawo daje prowadzące ku temu wytyczne. W związku z tym, że właśnie to ostatnie przykazanie, jako ingerujące w najintymniejsze sfery ludzkiego życia, budzi najwięcej kontrowersji, chciałabym kwestii nida i prawom dotyczącym czystości rodziny poświęcić więcej miejsca.

Tak jak w wielu kulturach na całym świecie także w judaizmie istnieje tabu związane z krwią menstruacyjną. Miesiączkująca kobieta nabywa odrębnego statusu zwanego nida. Jego podstawę stanowią dwa zbiory przepisów pochodzące bezpośrednio z Tory: przepisy dotyczące czystości i nieczystości rytualnej oraz przepisy odnoszące się do zakazanych czynności seksualnych.

Pojęcia czystości (tahara) i nieczystości (tuma) obejmują wiele obszarów. W stanie nieczystości rytualnej (prócz nida) można się znaleźć m.in. przez kontakt ze zwłokami, z padliną, z powodu upływu nasienia czy w związku z chorobą utożsamianą z trądem (carat) (Kpł 11-15). Podstawowe regulacje prawne dotyczące czystości i nieczystości znajdują się w Księdze Kapłańskiej i Księdze Liczb. W swojej istocie tabu czystości związane jest z pojęciem natury będącej niekontrolowanym przez człowieka przejawem życia i śmierci. Status czystości bądź nieczystości rytualnej określa, w którym miejscu pomiędzy życiem i śmiercią znajduje się dana istota lub przedmiot. Wraz ze zniszczeniem drugiej Świątyni Jerozolimskiej w 70 r. n.e. część przepisów dotyczących tuma przestała

${ }^{37}$ Owadja ben Awraham Bartenura, Komentarz do Miszny, Szabat 2:6:2. 
obowiązywać, a głównym przedmiotem tego zagadnienia stały się prawa związane z szeroko pojętą sferą seksualną, przenosząc problematykę czystości i nieczystości ze sfery publicznej do prywatnej.

Prawa dotyczące nida są przedmiotem częstego zainteresowania autorytetów rabinicznych. Przepisy te wywodzą się z regulacji obejmujących praktyki rytualne w Świątyni Jerozolimskiej. Czystość powinna być więc rozumiana jako stan zdolności człowieka lub przedmiotu do znajdowania się w miejscu Boskiej obecności takim jak Świątynia. Nieczystość jest natomiast stanem zakazującym człowiekowi pojawiania się w miejscu związanym z obecnością Boga lub dotykania czegokolwiek łączącego się z Jego obecnością ${ }^{38}$. Prawa dotyczące nida znajdują się w grupie przepisów określających przypadłości cielesne powodujące stan nieczystości.

Prawa odnoszące się do nieczystości kobiet są analogiczne do tych dotyczących mężczyzn i mogą być naturalne, spowodowane cyklem menstruacyjnym (nida) oraz stanem chorobowym (zawa). W przypadku nida okres nieczystości określa sama Tora i trwa on siedem dni. W przypadku zawa nieczystość uzależniona jest od czasu krwawienia. Krwawienie powoduje stan nieczystości nie tylko u samej kobiety, ale również przenosi się na ludzi i przedmioty, z którymi ma kontakt osoba nieczysta, jednak status ich nieczystości jest niższy (nieczystość drugiego stopnia). Przedmioty, które stały się nieczyste w wyniku kontaktu z osobą nida lub zawa, dalej przenoszą nieczystość (proces ten kończy się na nieczystości trzeciego stopnia). Wyjątkowa sytuacja następuje wtedy, gdy mężczyzna ma kontakt cielesny z krwawiącą kobietą - wówczas sam przyjmuje status podobny do nida ze wszystkimi tego konsekwencjami ${ }^{39}$.

Wyjątkowym przypadkiem, w którym kobieta nabiera statusu nida, jest poród, a czas trwania jej nieczystości uzależniony jest od płci narodzonego dziecka. Kobieta, która urodziła chłopca, staje się nieczysta na siedem dni, tak jak kobieta menstruująca. Dodatkowo, zgodnie z halachą, musi czekać kolejne trzydzieści trzy dni, zanim będzie mogła zanieść ofiarę do Świątyni. Po urodzeniu dziewczynki kobieta staje się nida na czternaście dni, a okres, zanim będzie mogła się oczyścić, wydłuża się o kolejne sześćdziesiąt sześć dni ${ }^{40}$. Okres poporodowej nieczystości można wytłumaczyć przyczynami biologicznymi - krwawienie po porodzie trwa przeważnie od czterech do sześciu tygodni. Jednak przyczyna, z której okres po porodzie dziewczynki

\footnotetext{
${ }^{38}$ Biale, Women and Jewish Law..., s. 148.

39 Tamże, s. 151.

40 Tamże.
} 
jest dwa razy dłuższy, nie jest do końca jasna ${ }^{41}$. Niektórzy badacze thumaczą to rozczarowaniem z powodu urodzenia dziecka mniej preferowanej płci $^{42}$, jednak teoria taka wskazywałaby na wiązanie nieczystości rytualnej z karą, co wydaje się nie korespondować z intencjami wyrażonymi w przepisach w Księdze Kapłańskiej ${ }^{43}$. Inni autorzy przypuszczają, że dwa razy dłuższy okres nieczystości w przypadku urodzenia dziewczynki może wynikać z tego, iż dziewczynka w przyszłości również będzie podlegać cyklom menstruacyjnym, w związku z czym kobieta jest niejako „podwójnie” nieczysta - za siebie i za swoją córkę ${ }^{44}$.

O ile Księga Kapłańska w dość jasny sposób określała zasady postępowania w przypadku kobiecej nieczystości, o tyle Talmud w zasadniczy sposób rozwinął i skomplikował przepisy z nią związane. Stworzono cały system instrukcji dla rabinów mających badać, czy krwawienie wynika z menstruacji, czy też ma charakter chorobowy, oraz czy powoduje ono stan nieczystości, czy też nie (TB, Nida 20a-20b). Z czasem ciężar badania przeszedł na same kobiety, które odtąd miały polegać przede wszystkim na swojej odpowiedzialności i dokładności w tym zakresie ${ }^{45}$. Potwierdzają to słowa rabbiego Zeiry: „Żydowskie kobiety były wobec siebie tak surowe, że nawet jeśli dostrzegły kroplę krwi wielkości ziarnka gorczycy, czekały siedem czystych dni” (TB, Nida 66a:18). Z powyższego fragmentu wynika, że pobiblijne prawo odnoszące się do czystości rytualnej stało się dużo bardziej restrykcyjne. Pierwotnie czas nieczystości związany z nida wynosił siedem dni, prawo rabiniczne wydłużyło okres o kolejnych siedem tzw. dni czystych, podczas których nie występuje krwawienie. Rabini porzucili także wyraźny rozdział na nida i zawa.

Podstawowym zagadnieniem związanym z prawem nida jest zakaz wszelkich kontaktów seksualnych w okresie nieczystości. Jak wspomniano wyżej, mężczyzna poprzez obcowanie z menstruującą kobietą nabiera statusu nieczystości równego nida. Kolejny rozdział Księgi Kapłańskiej umieszcza seks z kobietą będącą nida obok innych zakazanych czynności seksualnych, takich jak homoseksualizm męski czy zoofilia: „Nie będziesz się zbliżał do kobiety, aby odsłonić jej nagość, podczas jej nieczystości miesięcznej” (Kpł 18:19). Jeszcze inny fragment znajduje się wśród

41 Tamże.

42 Rachel Adler, Tum'ah and Taharah: Ends and Beginnings, [w:] The Jewish Woman: New Perspectives, red. Elizabeth Koltun, New York 1976, s. 69.

43 Tamże, s. 151.

44 Tamże.

45 Biale, Women and Jewish Law..., s. 152. 
przepisów mówiących o ochronie rodziny: „Jeżeli kto obcuje cieleśnie z kobietą mającą miesięczne krwawienie i odsłoni jej nagość, obnaża źródło jej [krwi], a ona też odsłoni źródło swojej krwi, to oboje będą wyłączeni spośród swojego ludu” (Kpł 20:18). Kara „wyłączenia spośród swojego ludu" (keret) była definiowana jako kara Boska, prawdopodobnie oznaczająca przedwczesną śmierć.

O ile kwestia czystości rytualnej w Torze związana jest przede wszystkim z możliwością kontaktu ze sferą sacrum i nie łączy się z pojęciem grzechu, o tyle sytuacja zmienia się w późniejszych księgach biblijnych. Termin nida zaczyna się odnosić do moralnej nieczystości oraz zepsucia:

Pan skierował do mnie te słowa: „Synu człowieczy, kiedy dom Izraela mieszkał na swojej ziemi, wówczas splugawili ją swym postępowaniem i swymi czynami: postępowanie ich wobec Mnie było jak nieczystość miesięczna kobiety (nida)” (Ez 36:17)

oraz

A teraz, Boże nasz, co powiemy, żeśmy po tym znowu przekroczyli Twoje przykazania, któreś nadał przez swoje sługi, proroków, tymi słowami: „Ziemia, w której posiadanie wchodzicie, jest ziemią splamioną przez rozpustę (erec nida) tych obcych narodów, przez ich obrzydliwości, którymi ją w nieczystości swej napełnili od końca do końca” (Ezd 9,10-11).

Po zniszczeniu Świątyni zmieniło się nie tylko rozumienie samej nieczystości, ale także przenoszenia jej na inne osoby i obiekty. Według Rasziego przepisy dotyczące przenoszenia nieczystości stały się bezprzedmiotowe, a zatem wszystkie przedmioty dotykane przez nida mogą być również dotykane przez innych. Przestrzeganie przepisów zawartych w rozdziale 15 Księgi Kapłańskiej nie powinno być rozpatrywane w kontekście nieczystości, ale ma akcentować odrębny status nida oraz separację z mężem, której ten stan wymaga. Zatem Raszi zabrania jedzenia z tego samego naczynia z nida, siadania na tym samym siedzeniu czy brania czegokolwiek bezpośrednio z rąk nida (chyba że za pośrednictwem osoby trzeciej). Postępowanie takie ma uchronić przed grzechem (awera $)^{46}$. Wszystkie działania, które wymienia Raszi, sprowadzają się do unikana wszelkich kontaktów mających charakter intymny między małżonkami. Status nida zaczyna więc być pojmowany jedynie w kontekście związków między mężem i żoną, przy czym zobowiązuje małżonków do unikania wszelkich kontaktów o charakterze intymnym.

46 Raszi, Responsa, nr 336. 
Przejście ze stanu nida do stanu czystości wymaga od kobiety wykonania rytuału polegającego na zanurzeniu w mykwie - łaźni rytualnej. Autorytety religijne pozostają zgodne co do opinii, że zanurzenie w mykwie (tewila) nie jest samo w sobie micwą. Tewila jest obowiązkiem, a więc micwą, tylko wtedy, gdy prowadzi do wznowienia kontaktów seksualnych między małżonkami ${ }^{47}$. Josef Karo dodaje, że kobieta, która się nie oczyszcza, aby dokuczyć mężowi, popełnia grzech ${ }^{48}$. Wznowienie czynności seksualnych po okresie oddzielenia jest - jak wynika z tego fragmentu - zależne od kroków poczynionych przez kobietę, dopóki bowiem nie zanurzy się ona w mykwie, dopóty zakazane jest podejmowanie przez nią jakichkolwiek czynności seksualnych.

Prawa odnoszące się do nida ewaluowały na przestrzeni wieków. Z grupy przepisów dotyczących rytualnej nieczystości stały się częścią zasad zapobiegających wykroczeniom seksualnym. Ze strefy publicznej weszły do sfery prywatnej. Intencją biblijnego prawa było wyłączenie kobiet nida z życia rytualnego w Świątyni, podczas gdy prawo pobiblijne przeniosło zakres obowiązywania przepisów na relacje mąż-żona i skupiło się na kontaktach małżeńskich w dużo większym stopniu niż na stosunkach $\mathrm{z}$ innymi osobami ${ }^{49}$.

Mimo że po zniszczeniu Świątyni w Jerozolimie stan nida dotyczył przede wszystkim sfery prywatnej, zdaniem części rabinów wciąż oddziaływał na sferę publiczną, a dokładniej - na możliwość udziału menstruującej kobiety w modlitwach wraz ze wspólnotą. W Sefer ha-pardes Raszi wyraził stanowisko, że nie ma halachicznych podstaw do wyłączenia kobiet będących nida z udziału w modlitwie publicznej. Zaznaczył jednak, że zwyczaj taki zasługuje na pochwałę. Podobnego zdania był Eliezer ben Joel ha-Lewi $(1140-1220)^{50}$. Według Rambama każdy, nawet będący w stanie nieczystości, ma prawo do uczestnictwa w modlitwie publicznej łącznie z czytaniem Tory oraz recytacją Szema ${ }^{51}$. W Szulchan aruch przyjęto pogląd Rambama ${ }^{52}$. Zasada ta odnosi się zarówno do kobiet, jak i mężczyzn znajdujących się w stanie rytualnej nieczystości. Mosze ben Jisrael Iserl w komentarzu do Szulchan aruch (Orach chajim) przywołał stanowisko XIII-wiecznego

${ }^{47}$ Josef Karo, Bejt Josef, Jore dea 193.

48 Tamże.

${ }^{49}$ Biale, Women and Jewish Law..., s. 158.

${ }^{50}$ Podaję za: Devorah Zlochower, May Woman Touch a Torah Scroll?, New York 2008, s. 11.

${ }^{51}$ Rambam, Miszne Tora, Kriat Szema 4:8.

${ }^{52}$ Karo, Szulchan aruch, Orach chajim 84:1, Jore dea 282:9. 
rabina Meira ha-kohena zakazujące krwawiącej kobiecie wchodzenia do synagogi, modlenia się czy dotykania zwoju Tory. Wspomniał wprawdzie, że istnieją odmienne praktyki w tym zakresie, zaznaczył jednak, że wśród części Żydów aszkenazyjskich obowiązuje pierwsze stanowisko ${ }^{53}$. Awraham Abele Gombiner podaje, że jako dobry zwyczaj przyjęto zakaz wchodzenia do synagogi czy patrzenia na zwój Tory ${ }^{54}$. Podobną opinię wyraził Awraham ben Jechiel Michael Dancig (1748-1820), zwracając szczególną uwagę na zakaz patrzenia na zwój Tory ${ }^{55}$. Większość komentatorów, nawet jeżeli opowiadała się za zakazem uczestnictwa kobiet będących w stanie rytualnej nieczystości w publicznej modlitwie, zauważała, że wywodzi się on ze zwyczaju będącego wyrazem skromności, nie jest zaś halachą samą w sobie ${ }^{56}$. Wydaje się również, że odmienne poglądy rabinów odzwierciedlają odrębną praktykę na poszczególnych obszarach geograficzno-kulturowych (głównie aszkenazyjskim i sefardyjskim) i inne obyczaje (minhag, nusach) w różnych społecznościach regionalnych.

Jeśli stan nida w niejednakowym stopniu oddziaływał na sferę publiczną, to konsekwencje w sferze prywatnej były dość jednoznaczne. Bycie nida eliminuje możliwość współżycia na co najmniej dwanaście dni w miesiącu. Pozytywne konsekwencje miały być dwojakiego rodzaju. Po pierwsze, okres odseparowania małżonków powinien wpływać na wzajemne pożądanie i fascynację po jego zakończeniu. Po drugie, kontakty seksualne odbywały się w najbardziej płodnym okresie kobiecego cyklu. Halacha w pełni reguluje rytm pożycia małżeńskiego, eliminując sporadyczność i uleganie erotycznym impulsom.

Prawa dotyczące nida, choć współczesnym wydawać się mogą jedynie opresyjnym reliktem, można rozpatrywać jako próbę zrekompensowania gorszej pozycji kobiety ${ }^{57}$. Chronią one bowiem kobietę przed byciem postrzeganą jako obiekt seksualny, a także mają zapobiegać przekształceniu małżeństwa w związek oparty wyłącznie na relacji seksualnej. Prawa nida ograniczają służebną rolę kobiety, ponieważ zgodnie z Talmudem część zwyczajowo spoczywających na kobiecie obowiązków domowych

${ }^{53}$ Podaję za: Zlochover, May Woman Touch..., s. 15.

${ }^{54}$ Gombiner, Magen Awraham, Orach chajim 88:2.

${ }_{55}$ Awraham ben Jechiel Michael Dancig, Chajej Adam, 1:3.

${ }^{56}$ Szneur Zalman z Ladów, Szulchan aruch ha-raw 88:2, na podstawie edycji: Shulchan Aruch: The Code of Jewish Law of Rabbi Shneur Zalman of Liadi, The Weiss edition, https://www.chabad.org/library/article_cdo/aid/3127874/jewish/Shulchan-Aruch-Harav. htm [dostęp: 6 kwietnia 2021].

57 Berman, The Status of Women..., s. 19. 
nie może być wykonywana w obecności męża w czasie jej nieczystości. Przepisy te mają więc chronić żonę przed przydzieleniem jej wyłącznie roli służącej ${ }^{58}$.

Chociaż oddziaływanie powyższych przepisów zdaje się ograniczać przede wszystkim do sfery domowej, określone przez autorytety religijne konsekwencje nieprawidłowego ich wypełniania są niezwykle surowe. Nieprzestrzeganie praw związanych z czystością rodziny oraz nakazu oddzielania chala mogło skutkować m.in. rozwodem bez odszkodowania umówionego w kontrakcie ślubnym - ketuba (Miszna, Ketuwot 7:6). Jeszcze surowsza kara, zdaniem rabinów, mogła spotkać kobietę z rąk samego Stwórcy: „Kobiety umierają przy porodzie z powodu trzech wykroczeń: jeśli nie są uważne przy przestrzeganiu praw nida, jeżeli nie są uważne przy oddzielaniu chala i jeśli nie są uważne przy zapalaniu świateł szabatowych" (Miszna, Szabat 2:6). Mimo że fragment ten może być próbą wytłumaczenia i nadania sensu śmierci kobiet, będącą dość powszechną w myśli rabinicznej teorią kary za grzechy, to jednak sformułowanie takiej teorii musiało wynikać z wagi, jaką przypisywano tzw. kobiecym micwot.

\section{Podsumowanie}

Chociaż Tora nie określa jednoznacznie roli i pozycji kobiety w społeczeństwie, późniejsze przepisy robią to już w sposób jednoznaczny. Rola żony i matki, choć niewskazana jednoznacznie w przepisach prawa, jest preferowana i poddana szczególnej ochronie.

Zgodnie z opinią Moszego ben Jisraela Iserla kobieta ma udział w nagrodzie swoich synów i męża, jeśli pomagała im w studiach religijnych $^{59}$. Zasada ta symbolizuje generalną pozycję kobiet $\mathrm{w}$ tradycyjnym judaizmie. Chociaż liczba micwot, z których kobiety są wyłączone, jest relatywnie mała, jednak ich waga jest znacząca. W efekcie kobiety nie biorą udziału w religijnym życiu publicznym, a ich rola - w najlepszym wypadku - ogranicza się do pasywnej ${ }^{60}$.

Prawo żydowskie w swoim założeniu kładzie nacisk na te potrzeby społeczności, których wyrazem jest silna pozycja rodziny i wzmacnianie więzów rodzinnych jako środka konsolidującego tę społeczność zarówno

\footnotetext{
58 Tamże.

59 Podaję za: Biale, Women and Jewish Law..., s. 40.

60 Tamże.
} 
duchowo, jak i fizycznie ${ }^{61}$. Potrzeby, a co za tym idzie - prawa jednostek, rozpatrywane są w kontekście interesu społecznego.

Wyłączenie kobiet z obowiązku przestrzegania niektórych micwot skutkuje ograniczeniem ich praw i stanowi zarazem przyczynę i konsekwencję ich nieobecności. Brak obowiązku studiowania Tory, przez wieki traktowany faktycznie jako zakaz, powodował nieobecność kobiet w systemie edukacji. W efekcie mężczyźni zdobyli monopol na znajomość prawa religijnego, dogmatów wiary, sprawowanie władzy sądowniczej, nauczanie w szkołach, a także czytanie i pisanie. Ulokowanie wiedzy w miejscach niedostępnych dla kobiet umocnił system stratyfikacji płci, spychając kobiety ze sfery publicznej do prywatnej ${ }^{62}$. Mimo zmian zachodzących w systemie edukacji ortodoksyjnej młodzieży kobiety w dalszym ciągu nie mają dostępu do edukacji religijnej na takim poziomie jak mężczyźni, nie mogą więc być rabinami, sędziami, kantorami, nie pełnią również funkcji związanych z przestrzeganiem prawa religijnego. W sferze publicznej i prawno-religijnej wciąż zdane są na reprezentację mężczyzn. Słuszny zatem wydaje się wniosek, że wyłączenie kobiety z przestrzeni publicznej jest istotą statusu kobiety skonstruowanego przez religijne prawo żydowskie.

Mimo to jednak tradycja żydowska stoi na stanowisku, że kobiety i mężczyźni, choć nie tacy sami, są równi. W sposób zdecydowany podkreśla się różnice fizyczne i psychiczne między kobietami i mężczyznami oraz wynikające stąd wyjątkowe, ściśle przydzielone role społeczne i religijne. Podkreślane i jednoznacznie określone role społeczne determinowane płcią w środowisku ortodoksyjnym stanowią powód do dumy, gdyż są przejawem harmonii Boskiego stworzenia.

\section{Bibliografia}

\section{1. Źródła opublikowane}

Biblia Tysiąclecia. Pismo Święte Starego i Nowego Testamentu, Poznań 2019.

Sefaria: A Living Library of Jewish Texts, https://www.sefaria.org/ [dostęp: 4 kwietnia 2021], z tej strony internetowej wykorzystano następujące teksty:

Abudarham Dawid ben Josef, Sefer Abudarham,

Bartenura Owadja ben Awraham, Komentarze do Miszny,

${ }^{61}$ Berman, The Status of Women..., s. 23.

${ }^{62}$ Daphne Spain, Gendered Spaces and Women's Status, "Sociological Theory” 11 (1993), nr 2, s. 137. 
Dancig Awraham ben Jechiel Michael, Chajej Adam, Falk Joszua ben Aleksander ha-kohen, Perisza, Gombiner Awraham Abele, Magen Awraham, Jaakow ben Aszer, Arbaa turim, Josef Chajim z Bagdadu, Ben Jehojada, Karo Josef, Bejt Josef, Karo Josef, Szulchan aruch, Miszna,

Mosze ben Jisrael Iserl, Mapa - komentarze do Szulchan aruch, Mosze ben Majmon (Rambam), Miszne Tora, Mosze ben Majmon (Rambam), Sefer ha-micwot, Mosze ben Nachman (Ramban), Milchamot ha-Szem, Szlomo ben Jicchak (Raszi), Komentarze do Talmudu, Szlomo ben Jicchak (Raszi), Responsa, Talmud babiloński,

Tanach, Tosefta.

Szneur Zalman z Ladów, Szulchan aruch ha-raw, na podstawie edycji: Shulchan Aruch: The Code of Jewish Law of Rabbi Shneur Zalman of Liadi, The Weiss edition, https://www.chabad.org/library/article_cdo/aid/3127874/jewish/Shulchan-Aruch-Harav.htm [dostęp: 6 kwietnia 2021].

\section{Opracowania}

Adler Rachel, Tum'ah and Taharah: Ends and Beginnings, [w:] The Jewish Woman: New Perspectives, red. Elizabeth Koltun, New York 1976.

Berman Saul J., The Status of Women in Halakhic Judaism, „Tradition” 14 (1973), nr 2.

Biale Rachel, Women and Jewish Law: An Exploration of Women's Issue in Halakhic Sources, New York 1984.

Frimer Aryeh, Women and Minyan, „Tradition” 23 (1988), nr 4.

Greenwald Zew, Bramy halachy. Religijne prawo żydowskie, red. Sacha Pecaric, tłum. Joanna Białek, Kraków 2005.

Rothstein Gidon, Women's Aliyyot in Contemporary Synagogues, „Tradition” 39 (2005), nr 2.

Spain Daphne, Gendered Spaces and Women's Status, „Sociological Theory” 11 (1993), nr 2.

Zlochower Devorah, May Woman Touch a Torah Scroll?, New York 2008.

Szoszana Keller Uniwersytet Marii Curie-Skłodowskiej w Lublinie szoszana.keller@gmail.com 